\title{
Non-legalized commerce in game meat in the Brazilian Amazon: a case study
}

\author{
Pedro Chaves Baía Júnior ${ }^{1}$, Diva Anelie Guimarães ${ }^{2} \&$ Yvonnick Le Pendu ${ }^{3}$
}

1. Directorate of Protected Areas, State Department of the Environment, Travessa Lomas Valentinas, 2717, Marco, CEP 66095-770, Belém-Pará-Brazil; baiajunior@yahoo.com.br

2. Institute of Biological Sciences, Federal University of Pará, Rua Augusto Corrêa, 01, Guamá, CEP 66075-110, BelémPará-Brazil; diva@ufpa.br

3. Department of Biological Sciences, State University of Santa Cruz, km 16, Rodovia Ilhéus/Itabuna, Salobrinho, Ilhéus BA, 45662-900, Brazil; yvonnick@uesc.br

Received 26-VII-2009. C Corrected 23-II-2010. Accepted 25-III-2010.

\begin{abstract}
In tropical forests, wild game meat represents an option or the only protein source for some human populations. This study analyzed the wildlife meat trade destined to human consumption in an open market of the Amazon rainforest, Brazil. Wildlife meat trade was monitored during 2005 through interviews to vendors and consumers in order to evaluate the socioeconomic profile of the sellers, the main species and byproducts sold, their geographical origin, commercial value, frequency of sale and product demand. Data indicated that vendors were financially highly dependant of this activity, getting a monthly income up to US\$271.49. During the survey, the amount of wildlife meat on sale added a total of $5970 \mathrm{~kg}$, as follows: $63.2 \%$ capybara (Hydrochoerus hydrochaeris), 34.4\% cayman (Melanosuchus niger and/or Caiman crocodilus crocodilus), 1.1\% paca (Cuniculus paca); $0.6 \%$ armadillo (Dasypus novemcinctus), $0.5 \%$ deer (Mazama americana), $0.2 \%$ matamata (Chelus fimbriatus), and $0.1 \%$ opossum (Didelphis marsupialis). Most of the commercialized species were not slaughtered locally. The consumption of wildlife meat was admitted by $94 \%$ of the interviewed, consisting of 27 ethno-species: 19 mammals, 6 reptiles, and 2 birds. The same percentage of the interviewed (94\%) already bought wildlife meat of 18 species: 12 mammals and 6 reptiles. The great amount of wildlife meat traded and the important demand for these products by the local population, point out the necessity to adopt policies for a sustainable management of cinegetic species, guaranteeing the conservation of the environment, the improvement of living standards, and the maintenance of the local culture. Rev. Biol. Trop. 58 (3): 1079-1088. Epub 2010 September 01.
\end{abstract}

Key words: biodiversity, economy, nutritional value, cultural importance, wildlife meat, non-legalized commerce.

Wild game meat is an important source of animal protein for many human populations around the world, causing socioeconomic impacts, particularly on populations in poorest regions such as tropical rainforests (Robinson \& Bennett 2000, Davies 2002), where it is still used as a source of income (Da Silveira \& Thorbjarnarson 1999, Clayton \& MilnerGulland 2000) or bartering object for others subsistence items (Lisboa 2002).

The importance of using this natural resource has led to a number of studies being performed in rural areas of the Amazon region, aiming to assess hunting activities conducted by local communities and their implications on biodiversity conservation (Ayres \& Ayres 1979, Bodmer et al. 1997, Emídio-Silva 1998, Lopes \& Ferrari 2000, Peres 2001, Ríos 2001, Bodmer et al. 2004, Bonaudo et al. 2005).

In the Brazilian Amazon, Peres (2000) suggests that the rural population alone probably consumes between 36392 and 89224 tons of game meat per year. In economic terms, this may represent an annual income 
between US\$ 77.8 and US\$ 190.7 million, considering the value of a kilo of game meat at US\$ 2.14. Bodmer et al. (2004) estimated that nearly 113000 mammals of different species were hunted yearly in the Loreto region of the Peruvian Amazon, providing an income of over US\$ 1 million.

Nevertheless, information is relatively scarce on game meat selling in open-air markets in different urban centers throughout the Amazon region (Sampaio 2003, Bodmer et al. 2004). Such information is difficult to obtain in the Brazilian Amazon, perhaps because buying and selling wildlife is an illegal activity (Brazil 1998). Most of the time, data is underestimated from confiscations of game meat performed by environmental agencies during inspection activities.

This paper presents a characterization of trade in wildlife and its food byproducts at the open-air market of Abaetetuba, an important city for illegal trade in Brazilian Amazon (Lopes 2003). We intend to use this information to assess not only ecological impacts of this activity but also the entire social, economic and cultural network it involves, in order to provide information that can underpin concrete activities to achieve sustainable management of Amazonian fauna species with commercial potential.

\section{MATERIALS AND METHODS}

This study was conducted at the openair market in the municipality of Abaetetuba ( $1^{\circ} 42.008^{\prime}$ S $\left.048^{\circ} 54.009^{\prime} \mathrm{W}\right)$, located some $52 \mathrm{~km}$ linearly West from Belém, Pará, Brazil. The following aspects were investigated in order to characterize trade in wildlife and its food byproducts: 1) the socioeconomic profile of the traders and their activity; 2) the main species and sub-products sold, origin, price and how often they were traded and 3) demand for purchase of these products.

The socioeconomic profile of the traders and their activity was investigated using a semi-structured interview with six salespersons, with a scripted questionnaire containing eighteen questions in five categories: characteristics of the trader (gender, age, schooling and time in activity); characteristics of the commercial activity (participation of other household members, main products sold, availability and access to resources and main buyers of their products); importance of activity to household income; use of game meat in household diet; and knowledge and attitude regarding legal aspects.

Four points of sale at the market were monitored in the period from January to December 2005. Others points were added from June to December 2005, and their number varied according to the availability of game meat for sale: two in June and July, three in August, eight in September, 10 in October, 11 in November and 10 in December.

Monitoring consisted in 17 visits that began around 7:30 a.m. and lasted an average of a half an hour, spending five to $10 \mathrm{~min}$. in each point-of-sale. Visits were conducted on Saturdays, with two exceptions. During certain months, only one visit was performed, while during others (March, April, July, August and September) two visits per month were conducted, always separated by an interval of more than one week. The minimum time of one week between consecutive visits was stipulated because salespeople stated that all meat was sold within three days at most. Therefore, we considered that all the meat sold during a visit was new, discarding the possibility of recounting a product.

The species on sale and characteristics of the meat, such as: origin, quantity $(\mathrm{kg})$ and price (US\$) were written on cards during each visit. Information per species on total average weight of meat (dried, salted and chilled) of capybara Hydrochoerus hydrochaeris and cayman (Melanosuchus niger and/or Caiman crocodilus crocodilus) was obtained from the salespeople themselves. For other species (Didelphis marsupialis, Mazama americana, Cuniculus paca and Dasypus novemcinctus), the total average weight of meat was determined by multiplying the number of animals on sale by the average of each species, as indicated by Emmons \& Feer (1997). 
Moreover, price surveys on other protein sources (beef steak, chicken, dried beef, mapará Hypophthalmus marginatus and fresh shrimp) were conducted five times during the year (January, April, July, October and December), for later comparison with sales prices of game meats.

One-hundred and thirty questionnaires were aleatorily given to persons that shopped at the open-air market in the period from April to November 2005, in order to verify the demand for game meat. A questionnaire was therefore prepared to acknowledge aspects on the use of fauna and some general characteristics of the interviewees. The method adopted by CoelhoFerreira \& Silva (2005) was used to verify ethno-species representation cited as consumed and purchased. This method calculates species representativity (RE) based on the number of informants that cited the species (Fce) divided by the number of informants citing the most cited species $\left(\mathrm{Fce}^{+}\right): \mathrm{RE}=\left(\mathrm{Fce} / \mathrm{Fce}^{+}\right) \times 100$.

Species that obtained a rate equal to or greater than $25 \%$ were considered as most representative.

\section{RESULTS}

All six traders interviewed were males, aged between 40 and 64, with most of them not having completed elementary school $(83.3 \%$, $\mathrm{n}=5)$. The majority $66.7 \%(\mathrm{n}=4)$ of interviewees had been trading in game meat for over twenty years, one assuring that he had been working in this activity for 50 years.

Most of the interviewees stated that they did not have any other activity and that this was the sole means of subsistence for the households $(83.3 \%, \mathrm{n}=5)$. The average monthly income obtained through this commercial activity, according to all interviewees, was around US\$ 271.49 (considering the dollar exchange rate on February 2006 as $R \$ 2.21$ ), which at the time of the interviews was equivalent of two minimum wages.

When asked about what alternatives might exist to legalize the buying and selling of game meat, interviewees mentioned the following factors: 1) political interest by the local government; 2) authorization by environmental authorities; 3 ) purchase of products from legal commercial animal raising facilities; and 4) revoking current environmental law. Half of those interviewed showed interest in buying products from legalized breeders although all salespersons stated that to their knowledge no such legalized source exists in the region.

In the interviews, salespersons informed that they only sold meat from the capybara, large (M. niger) and small cayman (C. crocodilus crocodilus), in addition to chicken, beef, several species of dried fish and salted cow udders. The oldest salesperson said that in the past, animals such as collared peccary (Pecari tajacu), agouti (Dasyprocta sp.), armadillo (Dasypodidae) and paca (C. paca) were often brought by fishermen from the state of Amazonas or from municipalities of the state of Pará, such as Tucuruí and Marabá.

During the monitoring of the points of sale we observed sale of matamata (Chelus fimbriatus), large and small cayman, opossum (D.marsupialis), armadillo (D. novemcinctus), deer (M. americana), capybara and paca. Only opossum and matamata were sold alive. Capybara meat was sold both dried with ribs and limbs as well as chilled. Cayman meat was observed dried, chilled and fresh. Armadillo, paca and deer meat was sold chilled (Fig. 1, Fig. 2).

A total of $5970 \mathrm{~kg}$ of game meat sales were recorded, with $1752 \mathrm{~kg}$ at the four points of sale monitored throughout the year of 2005 and 4 $218 \mathrm{~kg}$ at other points monitored during the period from June to December 2005.

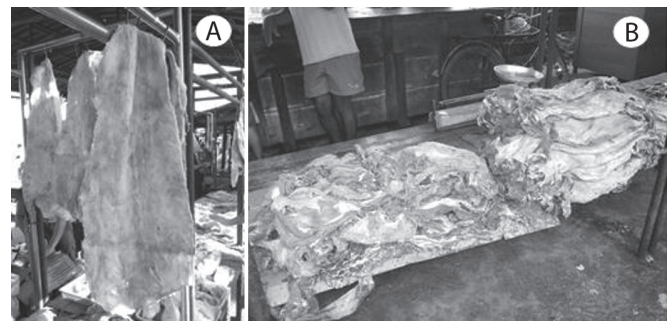

Fig. 1. Cayman (A) and capybara (B) meat was sold dried on the open-air market at Abaetetuba, Pará, Brazil. 

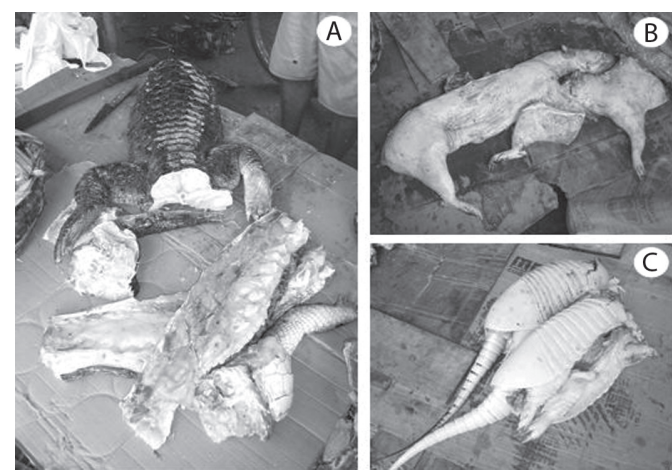

Fig. 2. Cayman fresh meat (A), paca (B) and armadillo (C) chilled meat sold at open-air marked in Abaetetuba, Pará, Brazil.

There is a considerable increase in supply of game meat from August to September. Even at the stalls monitored throughout the year, the amount of meat sold during the second half of the year doubled (647kg to $1105 \mathrm{~kg}$ ). Furthermore, there was an increase in the number of points selling cayman, capybara and less common species (D. marsupialis, M. americana, C. paca, D. novemcinctus and C. fimbriatus) during the second half of the year.

The largest amount of products sold (3 $905 \mathrm{~kg}, 65 \%$ ) was from mammals and the rest from reptiles, no other species were observed. The most representative game meats were those of the capybara and cayman, $63.2 \%$ (3 $775 \mathrm{~kg}$ $=3715 \mathrm{~kg}$ of dried meat and $60 \mathrm{~kg}$ of chilled

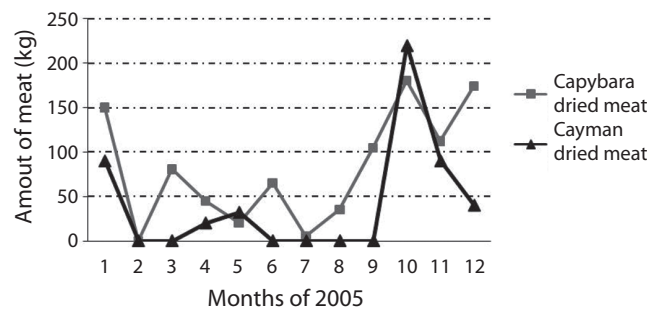

Fig. 3. Amount of capybara and cayman dried meat sold at the open-air market in 2005 .

meat $)$ and $34.4 \%(2052 \mathrm{~kg}=1630 \mathrm{~kg}$ dried and $422 \mathrm{~kg}$ fresh or chilled meat) respectively, followed by fresh or chilled paca meat $(1.1 \%$, $63 \mathrm{~kg})$, chilled armadillo meat $(0.6 \%, 36 \mathrm{~kg})$, chilled deer meat $(0.5 \%, 27 \mathrm{~kg})$, live matamata $(0.2 \%, 13 \mathrm{~kg}$, one animal) and live opossum $(0.1 \%, 4 \mathrm{~kg}$, four animals). The supply pattern of the two main types of meat sold at the four points monitored throughout the year (capybara and cayman) were highly differentiated, with capybara meat sold almost every month of the year, while cayman meat sales peaked in October (220kg) (Fig. 3).

Analyzing sales prices of game meat, we concluded that chilled paca, deer, armadillo and capybara reached higher prices than those obtained from dried capybara and cayman, whether dried or chilled (Table 1). By multiplying minimum and maximum sales prices by amounts of meat and live animals observed

TABLE 1

Sales price (US\$) of game meat and live animals sold at open-air marked in Abaetetuba, Pará, Brazil

$\begin{array}{llc}\text { Animal } & \text { Commercialization form } & \text { Price (US\$) } \\ \text { Cayman } & \text { dried meat } & 0.90-2.26(\mathrm{~kg}) \\ \text { Cayman } & \text { chilled and fresh meat } & 1.13-1.81(\mathrm{~kg}) \\ \text { Capybara } & \text { dried meat } & 1.58-2.71(\mathrm{~kg}) \\ \text { Opossum } & \text { live animal } & 3.17-4.07 \mathrm{a} \\ \text { Capybara } & \text { chilled meat } & 3.62(\mathrm{~kg}) \\ \text { Paca } & \text { chilled and fresh meat } & 4.07-4.52(\mathrm{~kg}) \\ \text { Armadillo } & \text { chilled meat } & 4.07-4.52(\mathrm{~kg}) \\ \text { Deer } & \text { chilled meat } & 4.52(\mathrm{~kg}) \\ \text { Matamata } & \text { live animal } & 6.79 \mathrm{a}\end{array}$

a. Animals were sold alive at a unique price, independently of their weight. 
for sale at the Abaetetuba open-air market in the year 2005, we were able to estimate that this commercial activity generated an amount between US\$ 8597.74 and US\$ 15 346.15.

Comparing monthly price fluctuations in dried capybara and dried or chilled cayman meat with other protein sources (Fig. 4) showed that both were cheaper than sale prices of beef steak and dried beef throughout the year. Nevertheless, capybara meat price rose in the months of April and July, nearing beef price. Capybara and cayman meat prices in January were nearly equal to those paid for mapará, fresh shrimp and chicken.

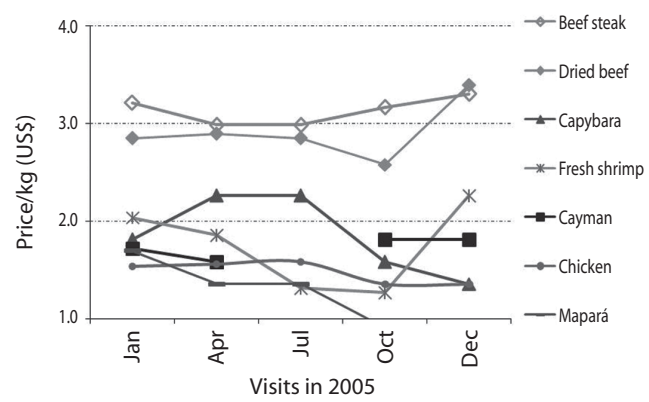

Fig. 4. Monthly price fluctuations (US\$) in dried capybara and dried or chilled cayman meat with other protein sources.

Capybara and cayman meat came, respectively, from the municipalities on the Marajó archipelago, especially from Soure, and from the state of Amazonas, where these animals were supposedly slaughtered, salted and laid out to dry. Fresh meat from other species were brought from several locations, especially sellers citing the state of Amazonas, for cayman, and some regions in the state of Pará, such as the Marajó archipelago and the municipalities of Tucuruí and Jacundá for capybara, deer, paca and armadillo. These animals and byproducts were sold to boat owners from Abaetetuba and neighboring municipalities who often traveled to these areas.

One-hundred and thirty people who were walking through the Abaetetuba open-air market were randomly interviewed in the months from April to November 2005. Of these, 53\% were male and $47 \%$ female, ranging in age from 20 to 73 . Almost all those interviewed (94.6\%) resided in the town, with $63 \%$ in the urban area and $37 \%$ in the rural zone, with the remaining interviewees coming from the municipalities of Barcarena, Igarapé-Miri and Moju.

A total of 122 (94\%) of those interviewed confirmed consumption of game meat, mentioning a total of 26 ethno-species (18 mammals, 6 reptiles and 2 fowls), 7 of which were most representative, as they were mentioned $25 \%$ or more of the time ( $\geq 24$ mentions). The species, in decreasing order of frequency of mention, were: capybara, opossum, cayman, armadillo, paca, deer and goldteju Tupinambis teguixin (Table 2). Moreover, $68 \%$ of the people who said they ate game meat stated they consumed as often as three times a week.

The main reason given by those interviewed who had never eaten game meat was that it did not taste good $(6 \%, \mathrm{n}=8$ responses).

The study also found that, among the 122 (94\%) interviewed who bought game meat, 114 bought and consumed the meat and 8 bought it but never consumed it. 18 ethno-species (12 mammals and 6 reptiles) were mentioned by the interviewed. Three of them were mentioned $25 \%$ of the time or more (i.e. $\geq 27$ mentions): capybara, cayman and opossum (Table 2).

The animal products purchased the last time and respective mention percentages by interviewees are presented in Fig. 5. Dried capybara and dried, fresh or chilled cayman

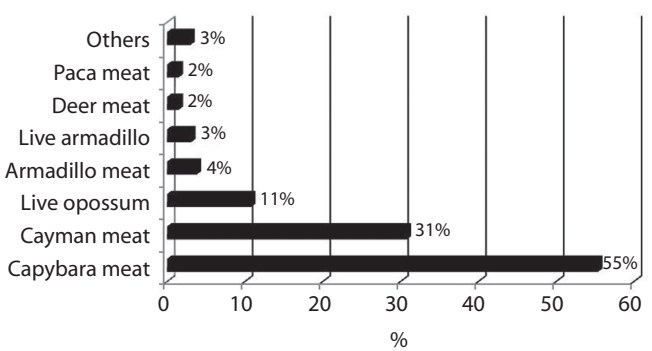

Fig. 5. The animal products purchased the last time and respective mention percentages by interviewees. 
TABLE 2

Ethno-species mentioned by interviewed at open-air marked in Abaetetuba, Pará, Brazil

\begin{tabular}{|c|c|c|c|c|c|}
\hline \multirow{2}{*}{ Taxa } & \multirow{2}{*}{ Ethno-species } & \multicolumn{2}{|c|}{ Consume } & \multicolumn{2}{|c|}{ Buy } \\
\hline & & Fce & RE (\%) & Fce & $\mathrm{RE}(\%)$ \\
\hline \multicolumn{6}{|l|}{ REPTILES } \\
\hline Iguana iguana & chameleon & 14 & 15 & 02 & 02 \\
\hline Tupinambis teguixin & goldteju & 24 & $25^{\mathrm{a}}$ & 03 & 03 \\
\hline Alligatoridae & cayman & 75 & $78^{\mathrm{a}}$ & 85 & $79^{\mathrm{a}}$ \\
\hline Geochelone sp. & land turtle & 11 & 11 & 14 & 13 \\
\hline Podocnemis expansa & turtle of the Amazonia & 11 & 11 & 13 & 12 \\
\hline Kinosternon scorpioides & mud turtle & 02 & 02 & 01 & 01 \\
\hline \multicolumn{6}{|l|}{ BIRDS } \\
\hline Crypturellus soui & littler tinamou & 01 & 01 & - & - \\
\hline Tinamidae & tinamou & 01 & 01 & - & - \\
\hline \multicolumn{6}{|l|}{ MAMMALS } \\
\hline \multicolumn{6}{|l|}{ DIDELPHIMORPHIA } \\
\hline Didelphis marsupialis & opossum & 78 & $81^{\mathrm{a}}$ & 47 & $44^{\mathrm{a}}$ \\
\hline \multicolumn{6}{|l|}{ XENARTHRA } \\
\hline Myrmecophagidae & giant anteater & 06 & 06 & - & - \\
\hline Bradypus variegatus & sloth & 12 & 13 & 04 & 04 \\
\hline Dasypodidae & armadillo & 54 & $56^{\mathrm{a}}$ & 25 & 23 \\
\hline \multicolumn{6}{|l|}{ PRIMATES } \\
\hline Alouatta belzebul & howler monkey & 05 & 05 & 01 & 01 \\
\hline \multicolumn{6}{|l|}{ CARNIVORA } \\
\hline Cerdocyon thous & fox & 01 & 01 & - & - \\
\hline Procyon cancrivorus & raccoon & 01 & 01 & - & - \\
\hline Nasua nasua & coati & 01 & 01 & - & - \\
\hline Panthera onca & jaguar & 08 & 08 & - & - \\
\hline \multicolumn{6}{|l|}{ PERISSODACTYLA } \\
\hline Tapirus terrestris & tapir & 06 & 06 & 02 & 02 \\
\hline \multicolumn{6}{|l|}{ ARTIODACTYLA } \\
\hline Tayassu pecari & white-lipped peccary & 09 & 09 & 04 & 04 \\
\hline Pecari tajacu & collared peccary & 08 & 08 & 03 & 03 \\
\hline Mazama sp. & deer & 29 & $30^{\mathrm{a}}$ & 24 & 22 \\
\hline \multicolumn{6}{|l|}{ RODENTIA } \\
\hline Hydrochoerus hydrochaeris & capybara & 96 & $100^{\mathrm{a}}$ & 108 & $100^{\mathrm{a}}$ \\
\hline Cuniculus paca & paca & 38 & $40^{\mathrm{a}}$ & 17 & 16 \\
\hline Echimyidae & spiny rat & 22 & 23 & 03 & 03 \\
\hline Dasyprocta sp. & agouti & 21 & 22 & 08 & 07 \\
\hline Coendou prehensilis & porcupine & 04 & 04 & - & - \\
\hline
\end{tabular}


meat were most frequently mentioned in the responses. Other products such as agouti, sloth and turtle meat were mentioned less frequently, jointly representing $3 \%$ of answers.

Wildlife products bought at the open-air market in Abaetetuba by those interviewed were mainly purchased to feed their families ( $84 \%)$, to give as gifts to relatives and/or friends that lived elsewhere ( $9 \%$ ), for resale in town or in the neighboring municipalities of Barcarena, Igarapé-Miri and Moju (6\%) or to supply restaurants with regional dishes $(2 \%)$.

The reasons that led people to buy these products were grouped into five different categories: 1) Savory taste of game meat (62\% of interviewees); 2) Diversify types of meat eaten at home and in restaurants $(20 \%) ; 3)$ The cultural habit of interviewees and their relatives and/or friends to eat game meat (10\%); 4) The possibility of obtaining income from sale of products to third parties, both in open-air markets as well as restaurants (4\%); and 5) The need for low-cost food (4\%).

\section{DISCUSSION}

The Abaetetuba open-air market is a public marketplace where food, farm products and merchandise is sold, even though is characterized by the sale of wildlife exclusively represented by the sale of game meat and live animals purchased illegally and sold for eating purposes. Contrary to other markets in the Amazon Region (Pinto \& Maduro 2003, Terra \& Rebêlo 2003), no sale of wildlife was observed for popular medicinal use or for handicraft products.

Data collected suggests that this market has been operating for several years as an important outlet for game meat, selling products from different parts of Amazonia. Contrary to the wildlife trafficking scheme described by Pontes (2003), which was characterized by a series of well-organized and highly complex steps, we observed that the linkages established up to the final sale of the product, at the Abaetetuba market, are much simpler and usually involve individuals of relatively low purchasing power.

Funds from sale of game meat are distributed among the different players involved in the commercialization chain established from capture to final sale of products at the market. The importance of wildlife trade to the income of households of certain communities in the Amazon has been highlighted by Pezzuti et al. (2004) who observed that fishermen at the Jaú National Park were able to earn more than one minimum wage salary per month just from selling turtles (Podocnemis unifilis).

Nevertheless, sellers earn very little per kilo of game meat sold, which obliges them to sell large amounts of meat to achieve the suggested income of US\$ 271.49 a month. According to Da Silveira \& Thorbjarnarson (1999), a kilo of dried cayman meat is sold by US\$ 0.90 by riverbank dwellers in Amazonas to middlemen, who sell it to the market stall owners at an average of US\$ 1.58 . With a hypothetical profit of US\$ 0.45 per kilo, the seller would have to sell $300 \mathrm{~kg}$ of dried cayman meat per month to obtain a minimum wage of US\$ 135.75 .

There was an increase in quantity and diversity of species sold at all the points of sale monitored during the second half of the year. Data from this study corroborates those presented by Da Silveira \& Thorbjarnarson (1999) on dried cayman meat sales from the state of Amazonas to the state of Pará, which affirms that most sales took place in the summer months (August-December), when hunting pressure on this species is higher. On the other side, we assume that the impossibility of drying capybara meat due to rains in winter is the main reason for the decrease in sales of this meat, throughout the first half of the year.

We expected higher supply of the remaining species during the first half of the year, coinciding with the rainy season, the period of greatest hunting pressure for most Amazonian species (Emídio-Silva 1998, De Almeida et al. 2002, Lisboa 2002). Nonetheless, it was only during the dry season (second half of year) that sales of these species were observed. 
Systematic monitoring of sales taken place throughout the year of 2005 enabled us to observe a larger number both of species as well as of amount of meat sold, than was observed by Sampaio (2003), who visited the same market only one day in the month of July of 2003. Even though we observed that significant increase in the amount and types of game meat sold comparing to the results obtained by the previously cited author, we believe that the data presented herein underestimates the true dimension of what is sold at the market, especially regarding the amount of game meat. Information collected suggests a significant amount of daily sales and therefore a more systematic monitoring would be required to accurately estimate the size of said trade.

The large amount of meat sold in Abaetetuba and the high percentage of local inhabitants who claim to buy some type of game meat at the market indicate that there is a significant demand for consumption of this type of meat in the municipality, especially by the urban population.

During the period in which sale of paca, armadillo and deer meat was observed at the market, local inhabitants often said they had these types of meat at home. Capybara meat is well received, with a regional dish based on this product served in local restaurants during certain periods of the year. This reflects the trend observed in some countries of Africa, where game meat consumption from illegal sources by urban populations with higher purchasing power is on the rise and interpreted as being one of the factors leading to overuse of the species (Postnote 2005).

Furthermore, the option for buying game meat in Abaetetuba and in other regions of the world (Clayton \& Milner-Gulland 2000) is more linked to cultural than to economic aspects. These products have been sold in large quantities even though prices for game meat is either near or even higher than average prices of other sources of protein.

This data contradicts the proposal put forth by Rushton et al. (2005) which affirms that local economic growth and greater productive efficiency in the ranching sector and fishing industry would reduce dependency on game meat in this region. Our results indicate that the local market does not consume game meat because it is sold at lower prices or due to lack of availability of other traditional animal protein sources. Cultural aspects and eating preferences better explain the existence of this market, as many consumers stated that this meat is tastier, and that they like to eat more than domestic meat.

Strategies are required to establish policies addressed to this type of activity. They must be based on adopting sustainable management programs and include elements to conserve target species of illegal trade and ensure legal means of access to a large portion of the Amazonian population, who have strong cultural ties with these resources.

Otherwise, as stated by Campos-Rozo \& Ulloa (2003), we shall follow the trend of many Latin American countries that, despite significant advances in the use and management of fauna as conservation strategies, still develop their public policies based on prohibition, without considering social and cultural conditions in the region.

\section{ACKNOWLEDGMENTS}

The Amazon Development Agency (ADA) for financing this project. Rosange Costa for her assistance in applying the questionnaires to the urban population of Abaetetuba. Conduí for making possible the contacts with salespeople at the market and valuable information.

\section{RESUMEN}

En los bosques tropicales, el consumo de carne silvestre representa una opción o la única fuente de proteínas para algunas poblaciones humanas. Este estudio analizó el comercio ilegal de carne de animales silvestres con fines alimenticios en un mercado de la Amazonia brasileña. El comercio de carne fue observado todo el año (2005), a través de entrevistas a los vendedores y consumidores, para la valoración del perfil socioeconómico de los comerciantes, determinar las principales especies y los subproductos vendidos, el origen geográfico, valor comercial, frecuencia 
de venta y demanda de los productos. Los datos indicaron que los comerciantes tenían una alta dependencia financiera de la actividad, obteniendo una renta mensual de US\$ 271.49. Se observó la comercialización de $5970 \mathrm{~kg}$ de carne silvestre y su consumo fue confirmado por $94 \%$ de los entrevistados, que reportaron 27 etnoespecies: 19 mamíferos, seis reptiles y dos aves. El mismo porcentaje de los entrevistados (94\%) han comprado carne de 18 especies silvestres: 12 mamíferos y seis reptiles. La mayoría del comercio ilegal de animales silvestres y la importante demanda de productos en la población local apuntan a la necesidad de políticas de desarrollo sostenible para las especies de caza, que garanticen la conservación del medio ambiente, una mejoría en la calidad de vida y la manutención cultural local.

Palabras claves: biodiversidad, economía, valor nutritivo, importancia cultural, sociedad, selva tropical

\section{REFERENCES}

Ayres, J.M. \& C. Ayres. 1979. Aspectos da caça no alto rio Aripuaña. Acta Amaz. 9: 287-298.

Bodmer, R.E., J.F. Eisenberg \& K.H. Redford. 1997. Hunting and the likelihood of extinction of Amazonian mammals. Conserv. Biol. 11: 460-466.

Bodmer, R.E., E.P. Lozano \& T.G. Fang. 2004. Economic analysis of wildlife use in the Peruvian Amazon, p. 191-207. In K.M. Silvins, R. Bodmer \& J.M.V. Fragoso (eds.). People and nature: wildlife conservation in South and Central America. Columbia University, New York, USA.

Bonaudo, T., Y. Le Pendu, J.F. Faure \& D. Quanz. 2005. The effects of deforestation on wildlife along the transamazon highway. Eur. J. Wildl. Res. 51: 199206.

Campos-Rozo, C. \& A. Ulloa. 2003. Perspectivas y tendencias en torno al manejo de fauna participativo en América Latina, p. 27-50. In C. CampoS-Rozo \& A. Ulloa (eds.). Fauna socializada: tendencias en el manejo participativo de la fauna en América Latina. Fundación Natura/MacArthur Foundation/Instituto Colombiano de Antropologia e História, Bogotá, Colombia.

Clayton, L. \& J. Milner-Gulland. 2000. The trade in wildlife in North Sulawesi, Indonesia, p. 473-496. In J.G. Robinson \& E.L. Bennett. Hunting for sustainability in tropical forests. Columbia University, New York, USA.

Coelho-Ferreira, M.R. \& M.F.F. da Silva. 2005. A fitofarmacopéia da comunidade pesqueira de Marudá, litoral paraense. Bol. Mus. Para. Emílio Goeldi, Ciências Naturais 1: 31-43.

Da Silveira, R. \& J.B. Thorbjarnarson. 1999. Conservation implications of commercial hunting of black and spectacled caiman in Mamirauá Sustainable Development Reserve, Brazil. Biol. Conserv. 88: 103-109.

Davies, G. 2002. Bushmeat and international development. Conserv. Biol. 16: 587-589.

De Almeida, M.B., E.C. de Lima, T.V. de Aquino \& M.P. Iglesias. 2002. Caçar, p. 311-335. In M.C. de Cunha \& M.B. De Almeida (eds.). Enciclopédia da floresta, o Alto Juruá: práticas e conhecimentos das populações. Companhia das Letras, São Paulo, São Paulo, Brasil.

Emídio-Silva, C. 1998. A caça de subsistência praticada pelos índios parakanã (Sudeste do Pará): características e sustentabilidade. Master Thesis, Universidade Federal do Pará, Pará, Brazil.

Emmons, L.H. \& F. Feer. 1997. Neotropical rainforest mammals: a field guide. University of Chicago, Illinois, USA.

Lisboa, P.L.B. 2002. Natureza, homem e manejo de recursos naturais na região de Caxiuanã, Melgaço, Pará. Museu Paraense Emílio Goeldi, Belém, Pará, Brazil.

Lopes, J.C.A. 2003. O tráfico internacional de animais silvestres, p. 15-49. In Renctas. Animais silvestres: vida à venda. Dupligráfica, Brasília, Distrito Federal, Brazil.

Lopes, M.A. \& S.F. Ferrari. 2000. Effects of human colonization on the abundance and diversity of mammals in eastern Brazilian Amazonia. Conserv. Biol. 14: 1658-1665.

Peres, C.A. 2000. Effects of subsistence hunting on vertebrate community in Amazonian forests. Conserv. Biol. 14: 240-253.

Peres, C.A. 2001. Synergistic effects of subsistence hunting and habitat fragmentation on Amazonian forest vertebrates. Conserv. Biol. 15: 1490-1505.

Pezzuti, J.C.B., G.H. Rêbelo, D.F. da Silva, J.P. Lima \& M.C. Ribeiro. 2004. A caça e a pesca no Parque Nacional do Jaú, Amazonas, Brasil, p. 213-230. In S.H. Borges (ed.). Janelas para a biodiversidade no Parque Nacional do Jaú: uma estratégia para o estudo da biodiversidade na Amazônia. Fundação Vitória Amazônica, Manaus, Amazonas, Brazil. 
Pinto, A.A.C. \& C.B. Maduro. 2003. Produtos e subprodutos da medicina popular comercializados na cidade de Boa Vista, Roraima. Acta Amaz. 33: 281-290.

Pontes, J.B. 2003. O tráfico internacional de animais silvestres, p. 173-191. In Renctas. Animais silvestres: vida à venda. Dupligráfica, Brasília, Distrito Federal, Brazil.

Ríos, G.Z. 2001. Sustentabilidad de la cacería de subsistencia: el caso de cuatro comunidades quichuas en la Amazonía nororiental ecuatoriana. J. Neotrop. Mammal. 8:59-66.

Robinson, J.G. \& E.L. Bennett. 2000. Hunting for sustainability in tropical forests. Columbia University, New York, USA.

Sampaio, P.A.M. 2003. Comércio ilegal de carne de animais silvestres em quatro feiras livres do estuário amazônico, Estado do Pará-Brasil. Trabalho de
Conclusão de Curso, Universidade Federal do Pará, Centro de Ciências Biológicas, Belém, Pará, Brazil.

Terra, A.K. \& G.H. Rebelo. 2003. Produtos da fauna de uso não alimentar comercializados em Manaus-AM, p. 31-32. In Anais do Congresso de Ecologia do Brasil. Fortaleza, Ceará, Brazil.

\section{INTERNET REFERENCES}

Brazil. 1998. Law $N^{\circ} 9605$, of the 12th of February of 1998. (Downloaded: January 05, 2006, www.planalto.gov.br/ccivil 03/LEIS/L9605.html).

Postnote. 2005. The bushmeat trade. (Downloaded: January 10, 2006, www.warmwell.com/bushmeat.pdf).

Rushton, J., R. Viscarra, C. Viscarra, F. Basset, R. Baptista \& D. Brown. 2005. How important is bushmeat consumption in South America: now and in the future? (Downloaded: January 10, 2006, www.odi.org.uk/ resources/download/2418.pdf). 